DOI: 10.17805/ggz.2018.5.7

\title{
Синдром выгорания как феномен в современной науке
}

А. И. Полянский,

Л. И. Быковская

Московский гуманитарный университет

В работе приводится описание исследования по вылялению особенностей феномена синдрома эмочионального выгорания (СЭВ), который является достаточно распространенным среди большого количества людей. Прежде всего, это обусловлено влиянием различных стрессов, в частности, рабочего стресса, которое все чаще и чаще испытывает на себе человек в современном мире.

Ключевые слова: синдром выгорания; эмочиональное выгорание; феномен выгорания; эмоциональное истощение

\section{Burnout Syndrome as a Phenomenon in Modern Science}

\author{
A. I. Polyansky, \\ L. I. Bykovskaya \\ Moscow University for the Humanities
}

The article describes a study to identify the characteristics of the phenomenon of emotional burnout syndrome, which is quite common among a large number of people. First of all, this is due to the influence of various stresses, in particular, work stress, which is increasingly experienced by people in the modern world.

Keywords: burnout syndrome; emotional burnout; phenomenon of burnout; emotional exhaustion

\section{ВВЕДЕНИЕ}

По данным Американского института стресса, рабочий стресс и последующее выгорание приводят к таким негативным явлениям, как текучесть кадров, абсентеизм, снижение продуктивности (Водопьянова, Старченкова, 2017: 34). Подтверждение этому приводит российский исследователь В. Е. Орел, который утверждает: «Существуют данные, что профессионалы с выраженными признаками выгорания настолько снижают эффективность своей деятельности, что это отражается на потере до 50 \% своего заработка» (Орел, 2014: 6).

Под термином «выгорание» понимается явление, характеризующееся устойчивостью, нарастанием отрицательных эмоций и, прежде всего, эмоци- 
онального истощения, а также появлением у человека дисфункциональных установок относительно своей работы, утратой мотивации. Основными симптомами этого негативного феномена принято считать эмоциональную истощенность, деперсонализацию (цинизм) и редукцию профессиональных достижений (ощущение своей неуспешности). В качестве научного феномена синдром выгорания начали исследовать с 60-70-х гг. ХХ века. Сам термин “burnout”, который можно перевести на русский язык как «эмоциональное» или «психическое выгорание», появился благодаря американскому психиатру Х. Фрейденбергеру, подробно описавшему данный феномен в своей статье “Staff burn-out” («Выгорание персонала») (Freudenberger, 1974). Под эмоциональным выгоранием он понимал состояние психически здоровых людей, которые находятся в тесном, интенсивном общении с пациентами / клиентами, т е. с объектами своего труда, при оказании профессиональной помощи в условиях насыщенной эмоциональной атмосферы (Ушакова, 2012: 61).

Синдром выгорания изучали многие зарубежные ученые и исследователи, среди которых наиболее известны К. Маслач и С. Джексон, К. Чернисс, А. Пайнз, Е. Арансон, А. Лэнгле. В России психологи начали изучать феномен выгорания в последнем десятилетии XX века. Среди отечественных исследователей, занимавшихся изучением данного феномена следует отметить В. В. Бойко, В. Е. Орла, Е. С. Страченкову, Н. Е. Водопьянову, Н. В. Гришину, Т. И. Ронгинскую и др. В 2017 г. в РИНЦ поступило более 500 публикаций по теме эмоционального выгорания, что свидетельствует о возрастающем научном интересе к данному феномену в России.

\section{СИНДРОМ ВЫГОРАНИЯ В МИРОВОЙ НАУКЕ}

После тщательного анализа существующей в настоящее время научной литературы, которая позволяет понять и раскрыть суть явления выгорания, можно сказать, что в зарубежной науке существует два основополагающих подхода к определению выгорания и выделению его симптомов: результативный и процессуальный (Орел, 2014). Согласно результативному подходу, выгорание - это некоторая законченная структура, подразумевающая совокупность определенных, конкретных элементов. Другой же подход сосредоточен на процессуальной стороне феномена, т. е. представляет выгорание в качестве некоторого процесса, который состоит из определенного количества стадий или фаз. Идея поэтапного формирования феномена прослеживается также в нескольких подходах, например, в трехстадиальная модель К. Чернисс (Cherniss, 1980, 1992), шестифазная концепции М. Буриша (Burisch, 1993), а также концепция Б. Перлмана и Е. Хартмана (Perlman, Hartman, 1982), рассматривавших выгорание в тесной связи со стрессом и стадиями его наступления (Чутко, Козина, 2015). 
Сторонниками результативного подхода являются А. Пайнз, Е. Аронсон, а также авторы наиболее известной и признанной модели выгорания - К. Маслач и С. Джексон. Ими была предложена наиболее известная и традиционная трехфакторная модель выгорания, согласно которой данный феномен представлен как мультифакторный, состоящий из трех основных компонентов (там же). К. Маслач не только дала свое определение синдрома выгорания, но и предложила метод его диагностики. По К. Маслач, выгорание состоит из таких подструктур:

1. Психоэмоциональное истощение (ПЭИ). Проявлениями ПЭИ могут быть усталость, чувство эмоциональной опустошенности, причиной которых является работа.

2. Деперсонализация - дегуманизация. Проявляется в изменении отношения к окружающим: обнаруживается негативный настрой, цинизм, адресованный коллегам или нуждающимся в помощи людям.

3. Редукция профессиональных достижений (РПД). Под РПД понимается чувство снижения эффективности деятельности, переживание собственной нерезультативности. Имеет место ощущение собственной несостоятельности и чрезмерности предъявляемых к нему требований.

Также к мультифакторному подходу относится модели, в которых количество факторов уменьшено до двух или, наоборот, увеличено до четырех. Например, двухфакторные модели синдрома выгорания предполагают отказ от какого-либо компонента структуры синдрома (по Маслач и Джексон) деперсонализации или редукции, оставляя другие два компонента - эмоциональное истощение и редукцию либо эмоциональное истощение и деперсонализацию соответственно (Чутко, Козина, 2015). Расширение же традиционной модели выгорания путем добавления еще одного компонента обусловлено спецификой некоторых исследований (Орел, 2014).

Как альтернатива мультифакторному подходу к изучению структуры выгорания существуют однофакторные модели, ярчайшим примером которых можно назвать модель А. Пайнза и Е. Aронсона (Pines, Aronson, 1981). Эти авторы рассматривают феномен выгорания так: «Состояние физического, психического и эмоционального истощения, вызванное длительным включением в ситуацию, которая предъявляет высокие требования к эмоциональной сфере» (Орел, 2014: 35). Под физическим истощением здесь А. Пайнз и Е. Аронсон понимают низкий энергетический тонус, слабость, постоянную усталость, а также физический и психосоматический дискомфорт.

Резюмируя материал, можно сделать вывод о том, что два, на первый взгляд, абсолютно противоположных подхода на феномен выгорания фоку- 
сируют внимание на разных сторонах явления: результативной и процессуальной.

\section{СИНДРОМ ВЫГОРАНИЯ В РОССИЙСКОЙ НАУКЕ}

С 1990-х гг. прошлого столетия феномен выгорания стал предметом самостоятельного изучения для российской науки, также стоит отметить, что исследования данной научной проблемы получили распространение как в России, так и в странах, входивших ранее в состав Советского Союза Украине, Белоруссии. В связи с этим в 1990-2000 гг. проводились различные эмпирические исследования разных авторов, таких как Н. Е. Водопьянова, Е. С. Старченкова, А. К. Маркова, М. В. Борисова и др.

Один из первых отечественных исследователей данной проблемы В. В. Бойко рассматривает феномен выгорания как вариант психологической защиты личности, заключающейся в частичном или абсолютном отказе от проявления эмоциональных реакций в травматических условиях (Бойко, 1996). Ученый относит синдром к формам профессиональной деформации личности и рассматривает его как стереотипное со стороны эмоций восприятие окружающей действительности, образующееся у профессионала в зависимости от совокупности внешних и внутренних факторов. Считая выгорание динамическим процессом и разделяя таким образом убеждения зарубежных сторонников процессуального подхода, Бойко вычленяет в развитии синдрома фазы, каждая из которых содержит в себе несколько симптомов: 1. фаза напряжения; 2. фаза резистенции; 3. фаза истощения (там же). Интересно, что, по мнению Бойко, явление выгорания как таковое не несет ничего отрицательного и даже является конструктивным, а дисфункциональная, негативно окрашенная сторона синдрома проявляется в его последствиях, которые негативно влияют на выполнение профессионалом своих должностных обязательств, а также на отношения с коллегами и прочими людьми.

Особый интерес и ценность для изучения феномена выгорания представляют труды российского ученого В. Е. Орла, занимавшегося как теоретическим, так и экспериментальным анализом феномена выгорания. В проведенном им исследовании (Орел, Серманова, 2008) получила эмпирическое подтверждение гипотеза Д. Ф. Гиллеспи (Gillespie, 1981), на которую ссылается В. Е. Орел, о различиях протекания выгорания: существует «пассивный» тип протекания, который характеризуется депрессивными симптомами, и «активный» тип, связанный с гневом, агрессией, раздражительностью. Орел условно назвал выделенные в результате исследования типы выгорания «стенический» (активный тип) и астенический (пассивный тип) (Орел, 2014: 49). При рассмотрении факторов, способствующих появлению выгорания, мы видим, что здесь могут оказывать влияние как личностные черты работника 
(этой точки зрения придерживается, например, польский психолог Т. И. Ронгинская), так и организационные моменты (мнение К. Маслач). Упомянутые выше Б. Перлман и Е. Хартман выделили следующие группы переменных, детерминирующих феномен выгорания в социономических профессиях: 1. личностные; 2. ролевые; 3. организационные. Таким образом, на появление синдрома выгорания влияют различные условия и предпосылки (Ушакова, 2012).

\section{СИМПТОМЫ ВЫГОРАНИЯ}

Феномен эмоционального выгорания включает в себя большое количество разнообразных симптомов. В зарубежной психологической литературе существует несколько классификаций симптомов выгорания, таких как классификации С. Кахилл (Kahill, 1988), Е. Л. Maxep (Maher, 1983), Дж. Ф. Кс. Кэролла и У. Л. Уайта (Carroll, White, 1982) (Чутко, Козина, 2015). Однако наиболее развернутая классификация по этой теме содержится в более поздней работе, принадлежащей В. Шауфели и Д. Энзманну (Schaufeli, Enzmann, 1998). Опираясь сразу на два основания, а именно на характер сферы индивида, которую симптомы представляют, и на уровень их проявления, авторы построили классификацию, насчитывающую в общей сложности 132 симптома, распределенных по следующим пяти группам: 1. аффективные; 2. когнитивные; 3. физические; 4. поведенческие; 5. мотивационные (Орел, 2014). Внимательно изучив данную классификацию симптомов выгорания, мы можем сказать, что она объединяет в себе довольно большое количество разнообразных симптомов и, следовательно, дает весьма объемную и многогранную картину структуры и содержания синдрома.

Как отмечают отечественные исследователи Н. Е. Водопьянова и Е. С. Старченкова, все многообразие симптомов выгорания не проявляется одновременно у одного человека, а составляют индивидуальные варианты, поскольку реакция выгорания проявляется у каждого по-разному (Водопьянова, Старченкова, 2017).

\section{ЗАКЛЮЧЕНИЕ}

Явление эмоционального выгорания представляет собой довольно неоднозначный и многогранный феномен. Возможно, именно поэтому на сегодняшний день в научном сообществе нет единого мнения и взгляда на эту проблему. Многие ученые и авторы концепций могут придерживаться совершенно противоположных точек зрения по этому вопросу. При этом проблема выгорания приобрела междисциплинарный характер и изучалась также представителями медицины, педагогики, социологии и других наук. Поэтому в разные годы как в России, так и за рубежом стали проводиться конферен- 
ции и съезды с целью обсуждения феномена выгорания. Одним из подобных мероприятий стала конференция, состоявшаяся в 1993 г. в Сан-Франциско, на которой западные психологи попытались сформулировать единую позицию относительно вопросов исследования выгорания. А. Л. Журавлев, Е. А. Сергиенко и их коллеги (Стресс, выгорание, совладание ... , 2011) подробно описывают в своей книге те положения, к которым удалось тогда прийти ученым:

1. Синдрому выгорания присуща трехкомпонентная структура, которая включает психоэмоциональное истощение, деперсонализацию и редукцию профессиональных достижений.

2. Выгорание является в некоторой степени необратимым феноменом.

3. Синдром выгорания носит общепрофессиональный характер, так как проявляется в рамках довольно разнообразных профессий. Тем не менее, прежде всего выгоранию подвергаются специалисты, задействованные в сфере профессий типа «человек - человек», связанных с оказанием той или иной помощи другим людям (там же: 391-392).

Однако авторы отмечают, что пока остаются разные мнения по поводу структуры и механизмов синдрома (там же).

Также тенденции к разработке однозначного подхода относительно синдрома выгорания были зафиксированы и в отечественной науке. Иллюстрируя это, А. Л. Журавлев, Е. А. Сергиенко и их коллеги обращают внимание на конференцию, проходившую в 2007 г. в Курске и предназначенную для обсуждения исследований синдрома выгорания у специалистов социономических профессий. Помимо российских ученых в конференции принимали участие представители бывших союзных республик (Белоруссия, Украина, Казахстан, страны Прибалтики,). А. Л. Журавлев, Е. А. Сергиенко и другие ученые констатируют: «Итогом данной конференции стало выработка единой позиции в понимании выгорания, создание Ассоциации исследователей данного феномена и издание коллективной монографии, свидетельствующей о сближении позиций исследователей в понимании выгорания, его структуры и механизмов возникновения» (там же: 392).

Таким образом, окончательная выработка единого мнения среди ученых относительно рассматриваемого феномена еще не достигнута, но существуют тенденции, объединяющие точки зрения относительно основных положений, характеризующих синдром выгорания. 


\section{СПИСОК ЛИТЕРАТУРЫ}

Бойко, В. В. (1996) Энергия эмоций в общении: взгляд на себя и на других. М. : Информационно-издательский дом «Филинъ». 472 с.

Водопьянова, Н. Е., Старченкова, Е. С. (2017) Психология управления персоналом. Психическое выгорание : учеб. пособие для академического бакалавриата. Изд. 3-е, испр. и доп. М. : Юрайт. 343 с. (Серия: Бакалавр. Академический курс. Модуль).

Орел, В. Е. (2014) Синдром психического выгорания. Мифы и реальность. Харьков : Гуманитарный центр. 296 с.

Орел, В. Е., Серманова, М. С. (2008) Исследование типологии психического выгорания у работников социальной сферы // Ярославский психологический вестник. Москва-Ярославль. Изд. «Российское психологическое общество». Вып. 23. С. 144-149.

Стресс, выгорание, совладание в современном контексте (2011) / авт. кол.: Г. А. Виленская, А. Л. Журавлев, Ю. В. Ковалева, Е. А. Лебедева, Е. А. Никитина, Е. А. Сергиенко ; под ред. А. Л. Журавлева, Е. А. Сергиенко. М. : Изд-во «Институт психологии РАН». 512 с. (Психология социальных явлений).

Ушакова, Т. А. (2012) Социально-психологические и индивидуальноличностные детерминанты состояния профессионального «выгорания» специалистов социальной работы // Отечественный журнал социальной работы. № 2. C. $60-70$.

Чутко, Л. С., Козина, Н. В. (2015) Синдром эмоционального выгорания. Клинические и психологические аспекты. Изд. 3-е. М. : МЕД-пресс информ. 256 c.

Burisch, M. (1993) In search of theory: Some ruminations on the nature and etiology of burnout // Professional burnout: Recent developments in the theory and research / ed. by W. B. Schaufeli, C. Maslach, T. Marek. Washington DC : Taylor \& Francis. xii, 299 p. P. 75-93.

Carroll, J. F. X., White, W. L. (1982) Theory building: Integrating individual and environmental factors within an ecological framework // Job stress and burnout: Research, theory and intervention perspectives / ed. by W. S. Paine. Beverly Hills ; L. ; New Delhi. 296 p. P. 41-60.

Cherniss, C. (1980) "Job burnout": Growing worry for workers, bosses // U.S. News and World Report. February 18. P. 71-72.

Cherniss, C. (1992) Long-term consequences of burnout: An exploratory study // Journal of Organizational Behavior. Vol. 13. No. 1. P. 1-11.

Freudenberger, H. J. (1974) Staff burn-out // Journal of Social Issues. Vol. 30. No. 1. P. 159-165. 
Gillespie, D. E. (1981) Correlates for active and passive types of burnout // Journal of Social Service Research. Vol. 4. No. 2. P. 1-16.

Kahill, S. (1988) Interventions for burnout in the helping professions: A review of the empirical evidence // Canadian Journal of Counseling Review. Vol. 22. No. 3. P. 162-169.

Maher, E. L. (1983) Burnout and commitment: A theoretical alternative // Journal of Counseling \& Development. Vol. 61. No. 7. P. 390-393. DOI: 10.1111/j.2164-4918.1983.tb00051.x

Perlman, B., Hartman, E. A. (1982) Burnout: Summary and future and research // Human relations. Vol. 35. No. 4. P. 283-305. DOI: 10.1177/001872678203500402

Pines, A. M., Aronson, E. (1981) Burnout: From tedium to personal growth. N. Y. : Free Press. 229 p.

Schaufeli, W. B., Enzmann, D. (1998) The burnout companion to study and practice: A critical analysis. L. : Taylor \& Francis. x, 220 p.

Дата поступления: 20.08.2018 2.

Полянский Андрей Иванович - доцент кафедры общей психологии и истории психологии Московского гуманитарного университета. Адрес: 111395, Россия, г. Москва, ул. Юности, 5, корп. 3, каб. 419. Тел.: +7 (499) 374-67-20. Эл. адрес: aipol-69@mail.ru

Быковская Любовь Игоревна - бакалавр четвертого года обучения, факультет психологии, педагогики и социологии Московского гуманитарного университета. Адрес: 111395, Россия, г. Москва, ул. Юности, 5, корп. 3. Эл. адрес: bikovskayali@mail.ru

Polyansky Andrey Ivanovich, Associate Professor, Department of General Psychology and History of Psychology, Moscow University for the Humanities. Postal address: R. 419, Bldg. 3, 5 Yunosti St., 111395 Moscow, Russian Federation. Tel.: +7 (499) 374-67-20. E-mail: aipol-69@mail.ru

Bykovskaya Liubov Igorevna, 4th year bachelor, Faculty of Psychology, Pedagogy and Sociology, Moscow University for the Humanities. Postal address: Bldg. 3, 5 Yunosti St., 111395 Moscow, Russian Federation. E-mail: bikovskayali@mail.ru

\section{Для ичитирования:}

Полянский А. И., Быковская Л. И. Синдром выгорания как феномен в современной науке [Электронный ресурс] // Горизонты гуманитарного знания. 2018. № 5. С. 85-92. URL: http://journals.mosgu.ru/ggz/article/view/874 (дата обращения: дд.мм.гггг). DOI: 10.17805/ggz.2018.5.7 